\title{
Ras Signaling is Involved in the Expression of Fas-L in Glioma
}

\author{
Bei-Chang Yang, Yuh-Sheng Wang, Hsiao-Sheng Liu, and Shio-Jean Lin \\ Departments of Microbiology and Immunology (B-CY, Y-SW, H-SL) and Pediatrics (S-JL), College of Medicine, \\ National Cheng Kung University, Tainan, Taiwan, Republic of China
}

\begin{abstract}
SUMMARY: Fas-L expresses on a variety of tumors and is suspected to modify the dialog between tumor and the immune system. However, the cellular abnormality in tumor cells leading to an aberrant expression of Fas- $L$ is unclear. In this study, we demonstrate the involvement of Ras signaling in the Fas-L expression in several ways. First, the activated Ha-ras ${ }^{\mathrm{Val} 12}$ gene enhanced the Fas-L expression of primary human glial cells. Second, blocking the Ras signal pathway in glioma cells by lovastatin or the Ha-ras ${ }^{\text {Asn17 }}$ dominant-negative mutant gene resulted in reduced Fas-L expression. Transfection of the Ha-ras ${ }^{\text {Asn17 }}$ into glioma cells also inhibited the activation of $\mathrm{NF} \kappa \mathrm{B}$, which is a downstream component of Ras signaling. Accordingly, the membrane-permeable NF $\kappa B$ competitor suppressed the Fas-L expression. Furthermore, the Fas- $L$ expression coincided with the Ras activity in the murine 212 cells, in which the Ras activity could be induced by isopropyl $\beta$-D-thiogalactoside. In summary, these results suggest that the enhanced Ras signaling with consequential $\mathrm{NF} \kappa \mathrm{B}$ activation, which is a frequent defect found in tumors, could mediate the Fas-L expression of tumors. (Lab Invest 2000, 80:529-537).
\end{abstract}

$F$ as-L (CD95L, APO-1L), a member of the tumor death signal into Fas-bearing cells by the engagement with Fas molecules (Itoh et al, 1991; Takahashi et al, 1994). Apoptosis triggered by the Fas/Fas-L signaling cascade is an important pathway involving not only homeostasis of the immune system (Chervonsky et al, 1997), but also embryo organogenesis (Seino et al, 1997; Yeh et al, 1998). In contrast to the tightly regulated expression in lymphocytes (Alderson et al, 1995; van Parijs and Abbas, 1996), Fas-L is constitutively expressed in several non-lymphoid tissues of immune privilege sites (Ferguson and Griffith, 1997). The recent findings that Fas-L-bearing melanoma and hepatoma cells induced apoptosis of $T$ cells in vitro (Hahne et al, 1996; Strand et al, 1996) and that tumorigenesis of melanoma cells was delayed in Fasdeficient Ipr mutant mice (Hahne et al, 1996) raise an interesting hypothesis that Fas- $L$ renders tumor to escape from immune surveillance (O'Connell et al, 1999; Walker et al, 1998). Since then, ectopic expression of Fas- $L$ has been found in many malignancies. Fas-L appears to modulate both immunosuppressive and proinflammatory immune responses in various tumor models (Walker et al, 1998). Despite the wealth of information, signaling in tumor cells for the Fas-L expression is not well elucidated.

Received Novemer 18, 1999.

Address reprint requests to: Dr. Bei-Chang Yang, Department of Microbiology and Immunology, College of Medicine, National Cheng Kung University, Tainan, Taiwan, Republic of China. Fax: 886-6-2082705; E-mail:y1357@mail.ncku.edu.tw
The NF $\kappa \mathrm{B}$ binding site, a downstream component of the Ras signaling, has been identified in the promoter region of Fas- $L$ gene and could affect the regulation of Fas-L in T cells (Faris et al, 1998; Latinis et al, 1997). Oncogenic mutations that alter the Ras activity have often been found in tumor cells (Kaba et al, 1990; Lowy and Willumsen, 1993). Therefore, we speculated that the trigger of the Ras signaling pathway that results in $\mathrm{NF} \kappa \mathrm{B}$ activation may mediate the Fas-L expression in tumor cells.

Glioma is one of the common tumors in the central nervous system and expresses a high level of Fas- $L$ (Gratas et al, 1997; Saas et al, 1997). Moreover, glioma cells showed high Ras activity because of either enhanced transcription of the $\mathrm{N}$-ras gene or reduced function of Ras suppressor RSU-1 (Tsuda et al, 1995; Tsurushima et al, 1996). Blocking the Ras activity by the Ha-ras ${ }^{\text {Asn17 }}$ dominant-negative mutant gene decreased cell proliferation, indicating that Ras is active and mediates an important mitogenic pathway in glioma (Guha et al, 1997). In this study, the Ras signaling in glioma cells was blocked by lovastatin, by Ha-ras dominant-negative mutant gene, or by the $\mathrm{NF} \kappa \mathrm{B}$ competitive peptides. Reductions in Ras and $\mathrm{NF} \kappa \mathrm{B}$ activities in treated cells were confirmed by luciferase-based reporter assays. Transcripts and protein levels of Fas-L in cells were detected by reverse transcription-polymerase chain reaction and flow cytometric analysis, respectively. Activated $\mathrm{Ha}$-ras ${ }^{\text {Val12 }}$ gene was transiently expressed in primary human glial cells to evaluate its effect on the Fas-L expression. In addition, we utilized an isopropyl $\beta$-D-thiogalactoside (IPTG)-inducible Ras expression system constructed in murine NIH3T3 cells to explore the association of the Ras activity and the Fas-L expression. 


\section{Results}

\section{Activated Ha-ras ${ }^{\text {Val12 }}$ Stimulated Fas $-L$ Expression in Glial Cell}

U-373MG and U118MG cells showed elevated expression of Fas- $L$ at both transcriptional and translational levels as compared with normal glial cells (Fig. 1, $\mathrm{a}$ and b). At 36 hours posttransfection with activated

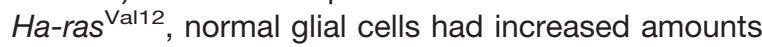
of Fas-L mRNA (Fig. 2a). Moreover, Fas-L-positive glial cells, being stained immunohistochemically with FasL-specific antibody, appeared in the EGFP-expressing cells, which would simultaneously receive $\mathrm{Ha}$-ras ${ }^{\mathrm{Val} 12}$ in this experimental condition (Fig. 2b). Normal glial cells transfected with pEGFP-N1 alone were flat and polygonal with little overlapping, whereas Ha-ras Val12 transfected glial cells became spindle form and overlapped.

\section{Lovastatin Suppressed the Expression of Fas- $L$ in Glioma Cells}

Treatment with $5 \mu \mathrm{g} / \mathrm{ml}$ lovastatin for 24 hours apparently did not affect the viability of U-373MG cells. $\mathrm{U}-118 \mathrm{MG}$ cells were relatively sensitive to lovastatin, that growth was reduced approximately $40 \%$ in 24 hours after treatment with $5 \mu \mathrm{g} / \mathrm{ml}$ lovastatin (data not shown). Treatment with lovastatin for 12, 24, or 36 hours, both U-118MG and U-373MG showed less Fas-L mRNA than DMSO-treated controls (Fig. 3a). The transcripts of Fas- $L$ expression were significantly reduced by lovastatin at 24 hours posttreatment, then gradually recovered. Decrease in Fas- $L$ protein level was further confirmed in 24 hours-lovastatin treated cells by flow cytometric analysis (Fig. 3b).

\section{Transfection of Ha-ras ${ }^{\text {Asn17 }}$ Suppressed the Ras Activity, the NFKB Activity, and the Fas-L Expression in Glioma Cells}

The inhibitory effect of $\mathrm{Ha}$-ras ${ }^{\text {Asn17 }}$ dominant-negative mutant gene on Ras activity in glioma cells was determined directly with the Pzy-luc reporter plasmid, which requires the Ras activity to express luciferase. By transfection with Pzy-luc alone for 24 hours, U-118MG cells showed a higher level of luciferase activity than U-373MG cells. Cotransfection with Pzyluc and Ha-ras ${ }^{\text {Asn17 }}$ significantly reduced the luciferase units of reporter in both $\mathrm{U}-118 \mathrm{MG}$ and U-373MG cells, as compared with those of Pzy-luctranfected cells, indicating that $\mathrm{Ha}$-ras ${ }^{\text {Asn17 }}$ inhibited effectively the Ras activity (Fig. 4a). Similarly, cells cotransfected with Ha-ras ${ }^{\mathrm{Asn} 17}$ and $\mathrm{NK} \kappa \mathrm{B}$-luc showed less luciferase units than cells transfected with $\mathrm{NK}_{\kappa} \mathrm{B}$ luc alone (Fig. 4b), indicating that Ha-ras ${ }^{\text {Asn17 }}$ also effectively suppressed the $\mathrm{NK}_{\kappa} \mathrm{B}$ activity.

After cotransfection with Ha-ras ${ }^{\text {Asn17 }}$ combining excess amounts of pEGFP-N1 and growth in fresh medium for 36 hours, cells were subjected to measuring Fas- $L$ protein by flow cytometric analysis gating on EGFP-positive population. Compared with transfection with an empty vector, expression of $\mathrm{Ha}_{\text {-ras }}{ }^{\text {Asn17 }}$ in glioma cells suppressed the Fas-L expression in glioma cells in two independent experiments (Fig. 4c).

(a) RT-PCR

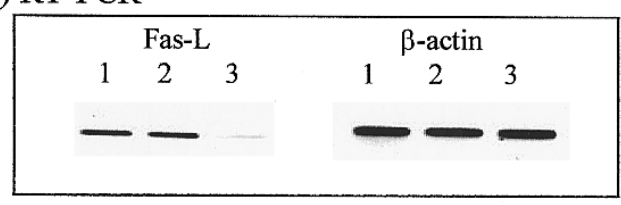

(b) FACScan

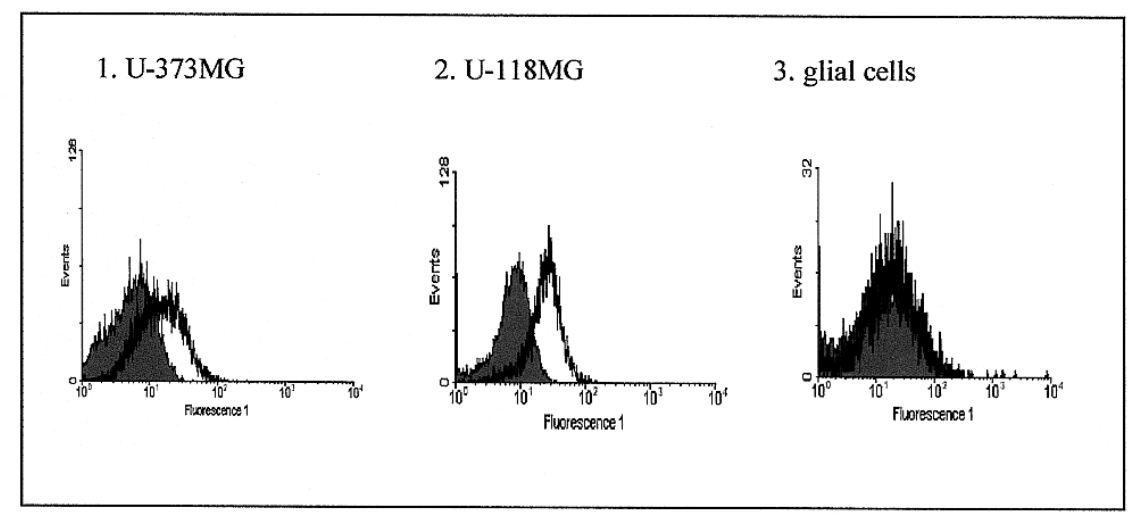

\section{Figure 1.}

Enhanced expression of Fas- $L$ in glioma cells. a, After growth for 2 days in 20\% FCS/DMEM, cells were harvested. Fas- $L$ transcripts were analyzed by RT-PCR. Lanes 1 to 3: U-373MG, U-118MG, and normal glial cells, respectively. b, Level of Fas-L protein was detected by flow cytometry analysis with antibody recognizing human Fas-L. Staining with secondary antibody alone was the negative control. 
(a) RT-PCR

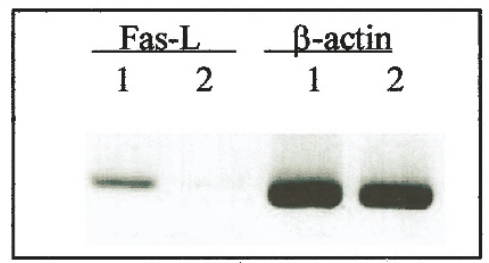

(b) Representative photograph of Fas-L/EGFP double positive cells

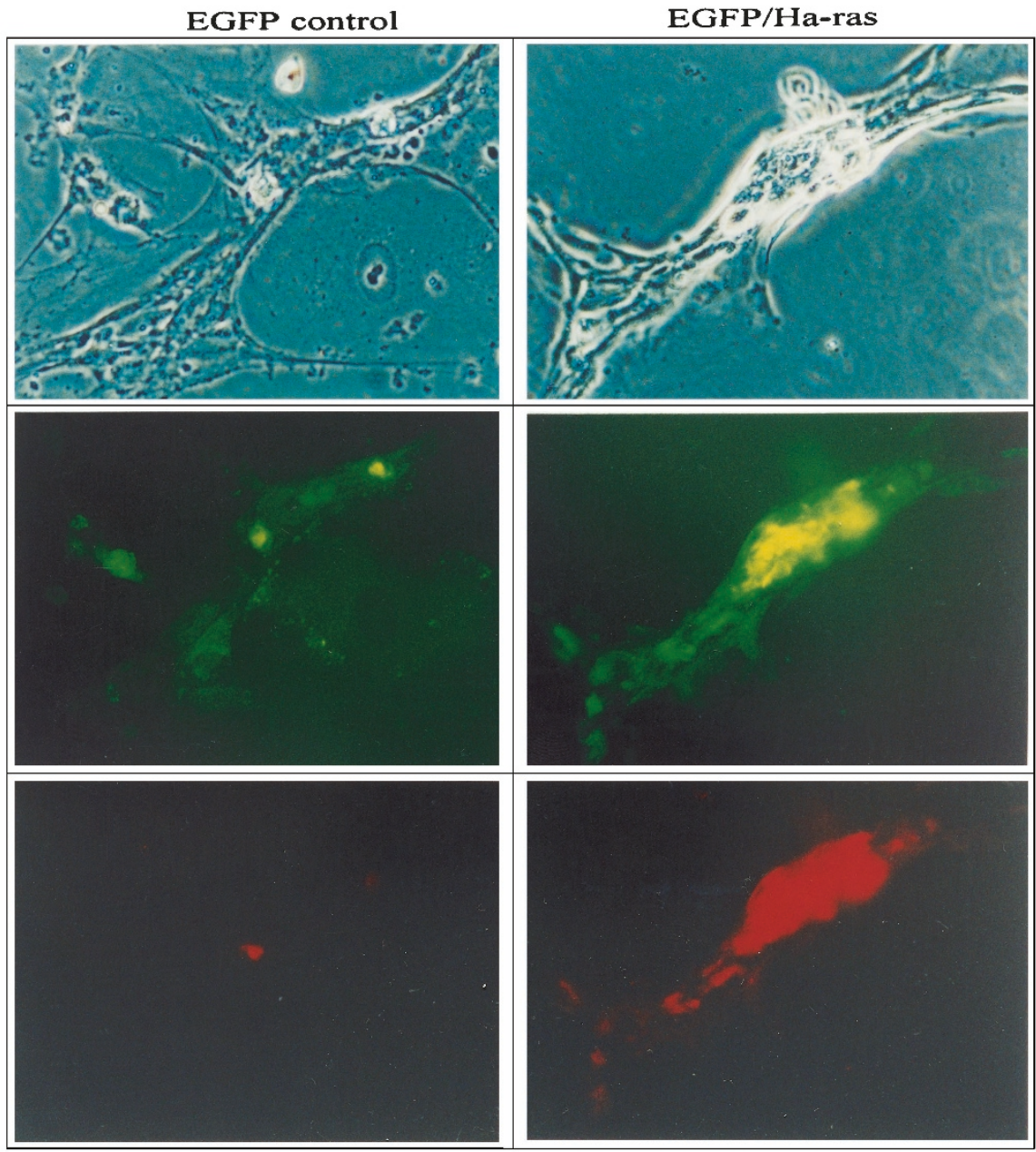

\section{Figure 2.}

Activated Ha-ras ${ }^{\mathrm{val} 12}$ gene stimulated the expression of Fas-L in normal glial cells. DNA transfection was done as described in "Material and Methods." Levels of Fas-L were compared in 36 hours posttransfected cells. a, The transcripts of Fas-L were analyzed by RT-PCR. Lane 1, Ha-ras val12 plus pEGFP-N1; Lane 2, pEGFP-N1 alone. b, Fas-L protein was immunohistochemically stained using PE-labeled Fas-L specific antibody. Upper panel, light microscopy; middle panel, EGFP-fluorescence; lower panel, Fas-L staining.

\section{Suppression of Fas-L Gene in Glioma Cells by NFкB Competitive Peptide}

Cells treated with membrane-permeable NF $\kappa \mathrm{B}$ competitive peptide for 24 hours were harvested and subjected to detection on mRNA by RT-PCR and protein and by flow cytometric analysis. NF $\kappa$ B competitive peptide significantly reduced the amounts of
Fas-L transcript (Fig. 5a), as well as protein (Fig. 5b) in glioma cells as compared with those of control.

\section{Expression of Fas-L Coincided with the Ras Activity in 212 Cells}

On exposure to $2.5 \mathrm{~mm}$ IPTG for 24 hours, 212 cells expressed elevated amounts of Ras protein (Fig. 6a). 
(a) RT-PCR

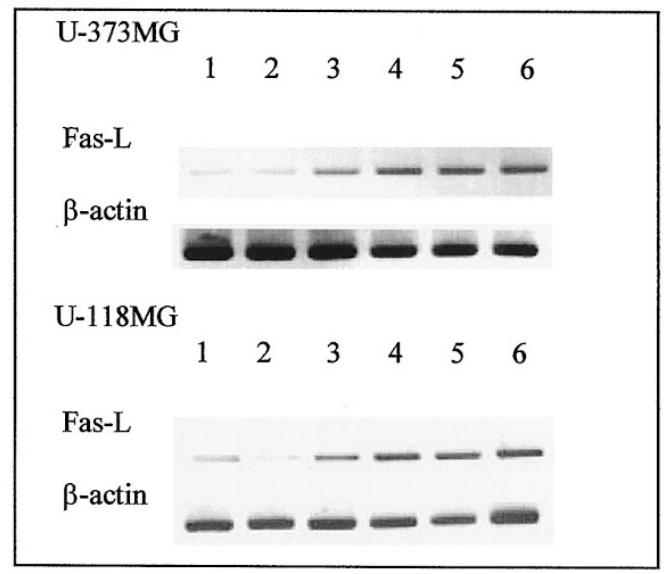

(b) FACScan

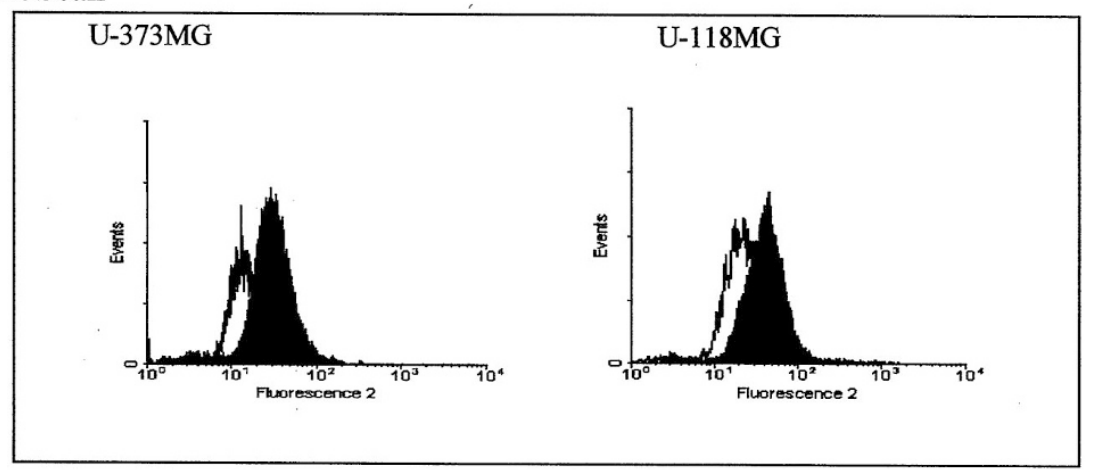

\section{Figure 3.}

Effect of lovastatin on Fas-L. After treated with either $5 \mu \mathrm{g} / \mathrm{ml}$ lovastatin (Lanes 1 to 3 ) or DMSO (Lanes 4 to 6 ), cells were harvested at intervals. a, The Fas-L transcripts were analyzed by RT-PCR. Lanes 1 and 4, 12 hours; Lanes 2 and 5, 24 hours; Lanes 3 and 6, 36 hours posttreatment. b, Fas-L protein in cells treated with lovastatin for 12 hours was detected by flow cytometry analysis. Lovastatin-treated cells, blank curve; DMSO-treated cells, filled curve.

The Ras activity in 212 cells reached maximal in 24 hours after induction with IPTG. Accordingly, the Ras activity in IPTG-treated 212 cells, revealed by the luciferase units in measurement with Pyz-luc reporter, was enhanced approximately to 3.5-fold over mocktreated cells. The expression of Fas-L, both at RNA and protein levels, agreed well with the Ras activity in 212 cell upon IPTG induction (Fig. 6b).

\section{Discussion}

We provide evidence to show an active participation of Ras signaling in the Fas- $L$ expression. Transfection with the activated $\mathrm{Ha}-\mathrm{Ras}^{\mathrm{Val12}}$ gene enhanced the Fas-L expression in normal glial cells. Conversely, suppressing Ras signal pathway in glioma cells by lovastatin, Ha-Ras ${ }^{\text {Asn17 }}$ dominant-negative mutant gene or NFkB competitive peptide could downregulate the Fas- $L$ expression. The suppression of $\mathrm{NF}_{\kappa} \mathrm{B}$ activity that resulted in reduced Fas $-\mathrm{L}$ in glioma cells is consistent with the findings that $\mathrm{NF} \kappa \mathrm{B}$ binding to the Fas- $L$ promoter region is required for the Fas- $L$ expression in T cells (Chen et al, 1997; Kasibhatla et al, 1998). NF $\kappa$ B has been known to be a downstream mediator of Ras signaling pathway, and may regulate the transcription of genes for cell survival and immune responses (Ljungdahl et al, 1997). As expected, HaRas $^{\text {Asn17 }}$ dominant-negative mutant gene inhibited not only the Ras activity but also the NF- $\kappa$ B activity in glioma cells. Our results indicate that the Ras signaling in glioma is transmitted down through NF $\kappa \mathrm{B}$ to activate Fas-L. Furthermore, the stimulatory effect of Ras on the Fas- $L$ expression was demonstrable in murine fibroblast-like cells with an IPTD-inducible Ras system, suggesting that Ras signal-regulated expression of Fas- $L$ might be common in malignant cells of different origins.

Ras protein has been known to transduce multiple signals regulating cell growth (Campbell et al, 1998; White et al, 1995). As mentioned earlier, Ras dominant-negative mutants decrease the proliferation of astrocytoma cell lines (Guha et al, 1997). We failed to establish a stable cell clone carrying Ha-Ras ${ }^{\text {Asn17 }}$ dominant-negative mutant gene (data not shown), which further confirms the essential role of Ras mitogenic pathway for the survival of glioma cells. Recently, accumulated information has shown that Ras could also mediate immune down-regulation through several growth-unrelated mechanisms (Weijzen et al, 
(a) Luciferase activity (Pzy-luc)

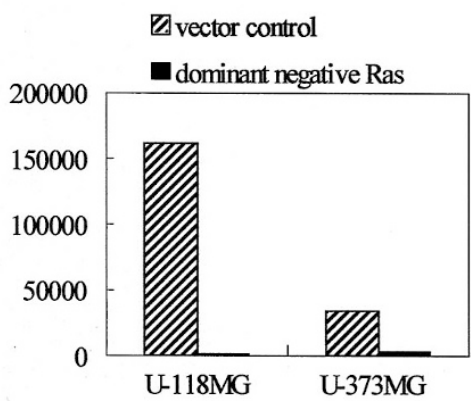

(b) Luciferase activity (pNFkB-luc)

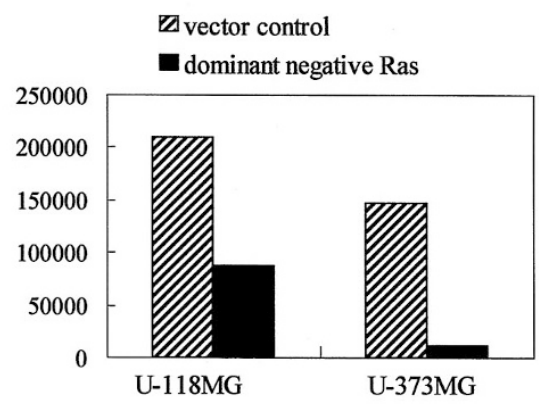

(c) FACScan analysis on Fas-L

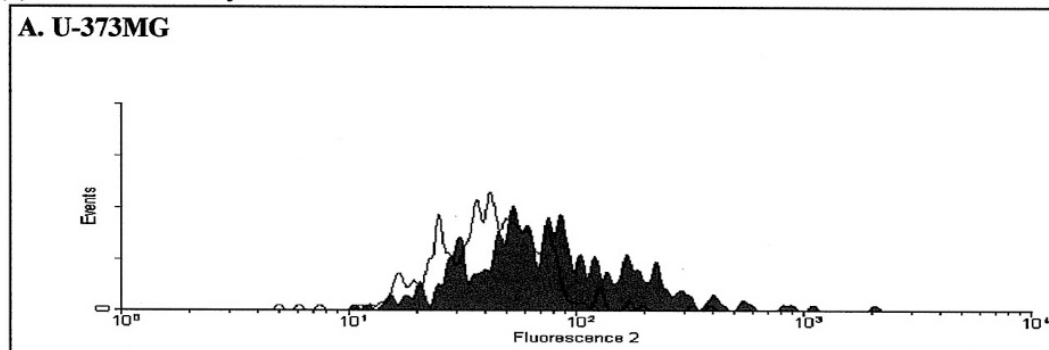

B. U-118MG

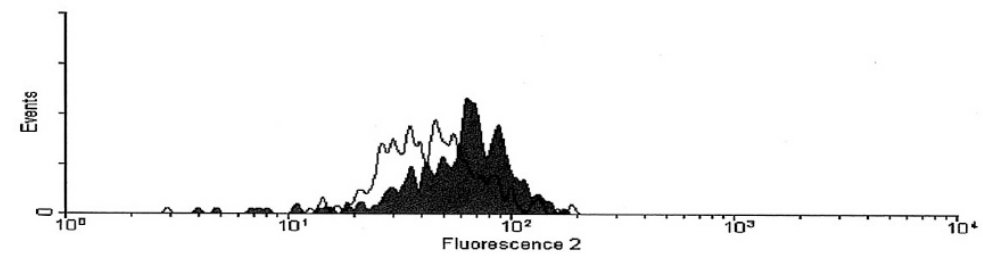

\section{Figure 4.}

Effect of Ha-ras ${ }^{A s n 17}$ dominant-negative mutant gene on Ras, NF $\kappa$ B, and Fas-L. Cells were cotransfected with Ha-ras ${ }^{A s n 17}$ and pEGFP-N1 and grown further for 36 hours. Relative luciferase units detected by a, Pzy-luc reporter and b, pNF $\mathrm{B}^{\mathrm{B}-l u c}$ reporter reflect the activities of Ras and NF $\mathrm{B}^{\mathrm{B}}$, respectively. Values shown are means of two independent experiments. C, Fas-L protein stained with Fas-L-specific antibody was detected by flow cytometry analysis gating on EGFP-positive cell. Blank curve, $\mathrm{Ha}$-ras ${ }^{\mathrm{Asn} 17} / \mathrm{pEGFP-N1-transfected;} \mathrm{filled} \mathrm{curve,} \mathrm{pEGFP-N1-transfected.}$

1999). For instances, high Ras expression is correlated with an increased level of invasiveness of breast cancer, in which Ras has been linked to MHC downregulation (Solana et al, 1992). In addition, Rasexpressing tumors are shown to have a marked decrease in Fas or TNF- $\alpha$ receptor, which renders tumors resistant to cytotoxic T cell-mediated killing (Fenton et al, 1998; Fernandez et al, 1992). These immune-associated mechanisms can explain the observations that the Ras confers progression and metastasis of some cell lines in vivo, but does not alter significantly the growth rate of those cells in vitro (Muschel et al, 1985; Wang et al, 1997). Taken together, our finding supports the idea that oncogenic potential of Ras may reside in the capacity not only to promote cell growth, but also to defeat immune surveillance by increasing the expression of Fas-L.

\section{Materials and Methods}

\section{Cell Culture}

Human glioma cell lines U-373MG and U-118MG were purchased from the American Type Culture Collection (Rockville, MD). Brain tissues were obtained from patients who underwent operations at National Cheng Kung university Hospital for brain damage that was unrelated to malignancy. Primary explant cultures of normal glial cells were then established according to a method described elsewhere (Yong et al, 1991). Cells were cultured in Dulbecco modified Eagle's medium (DMEM; Gibco BRL, New York) supplemented with $20 \%$ fetal calf serum (FCS), $1 \%$ penicillin, and $1 \%$ fungizone at $37^{\circ} \mathrm{C} / 5 \% \mathrm{CO}_{2}$. The 212 cells, derived from NIH3T3 cells and mounted with an isopropyl $\beta$-D-thiogalactoside (IPTG; 2.5 mm; Sigma Chemical, 
(a) RT-PCR

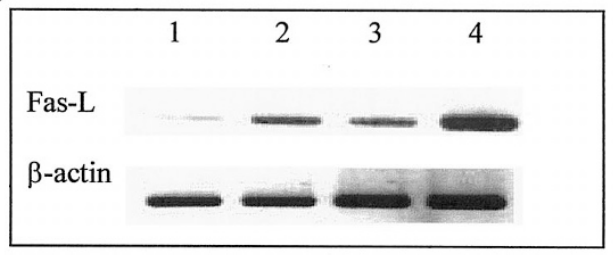

(b) FACScan analysis

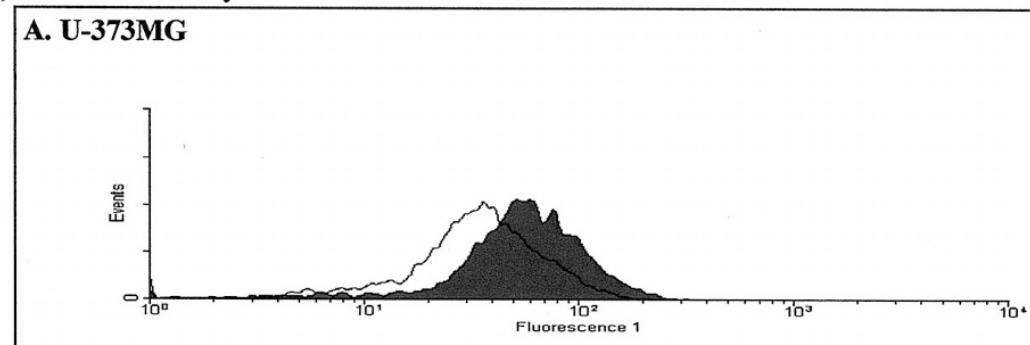

B. U-118MG

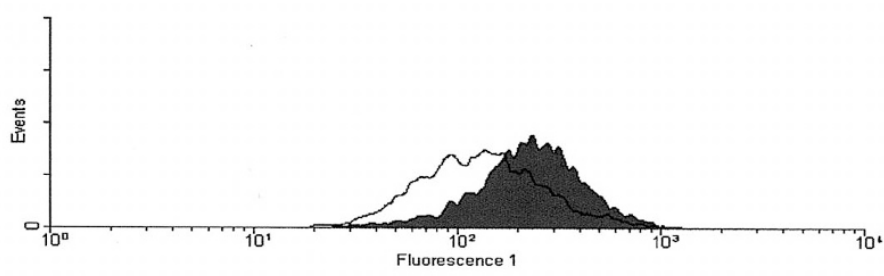

Figure 5 .

Effect of NF $\kappa$ B competitive peptide on Fas-L. Treated with $50 \mu \mathrm{g} / \mathrm{ml} \mathrm{NF \kappa B}$ competitive peptide for 24 hours, cells were harvested for analysis on Fas-L. a, The Fas- $\mathrm{L}$ transcript was analyzed by RT-PCR. Lanes 1 and 2, U-373MG; Lanes 3 and 4, U-118MG. b, Fas-L protein was detected by flow cytometry analysis using Fas-L-specific antibody. Blank curve, NFKB competitive peptide-treated; filled curve, mock treated.

St. Louis, Missouri)-inducible Ras system (Liu et al, 1992, 1998), were grown in 10\% FCS/DMEM. Standard Chem. and Pharm. Co., Taiwan, Republic of China, kindly provided us with lovastatin, which is a competitive inhibitor of 3-hydroxyl-3-methylglutaryl coenzyme $A$ reductase and inhibits the translocationassociated isoprenylation of several Ras family proteins, resulting in loss of their signal transducing ability (Cuthbert and Lipsky, 1997; Girgert et al, 1994). NF $\kappa B$ activity was inhibited by the membrane-permeable $\mathrm{NF} \kappa \mathrm{B}$ competitive peptide (50 $\mu \mathrm{g} / \mathrm{ml}$; BIOMOL Research Laboratories, Plymouth Meeting, Pennsylvania) according to the manufacturer's instructions.

\section{DNA and Transfection}

Plasmid DNA was delivered into cells by lipofection with a ratio of $1 \mu \mathrm{g}$ DNA/20 $\mu 1$ lipofectamine (SuperFect Transfection Reagent; Qiagen, Hilden, Germany). After transfection, cells were grown in fresh $20 \%$ FCS/DMEM for 24-36 hours then harvested for detections on Fas-L, Ras, or NF $\kappa$ B. pEGFP-N1 plasmid
(Clontech, Palo Alto, California) was used as the control to evaluate transfection efficiency and to label transfection-positive cells. EGFP-expressing cells were green under fluorescent microscopy. Ha-ras ${ }^{\mathrm{Val12}}$ is an activated mutant cloned from the human T24 bladder carcinoma cell line (Capon et al, 1983). Dominant-negative mutant $\mathrm{Ha}_{\text {-ras }}{ }^{\text {Asn17 }}$ (pZipAsn17; Feig and Cooper, 1988) was kindly provided by Dr. S.F. Yang (Academia Sinica, Taiwan, Republic of China). The transfection efficiency was approximately $10 \%$ in this experimental condition. By cotransfection experiments, plasmids coding $\mathrm{Ha}$-ras ${ }^{\mathrm{Val} 12}$ activated mutant or Ha-ras ${ }^{\text {Asn17 }}$ dominant-negative mutant were mixed with the pEGFP-N1, Pzy-luc, or the NK $\kappa \mathrm{B}$-luc at a ratio of 9:1. The excess amounts of reporter plasmids over Ras plasmids ensured that those pEGFPN1-, Pzy-luc-, or NKкB-luc-transfected cells might simultaneously receive the Ha-ras ${ }^{\mathrm{Val12}}$ or $\mathrm{Ha}$-ras ${ }^{\mathrm{Asn17}}$.

\section{Luciferase Reporter Systems for Ras and NFאB Activities}

The luciferase-base reporter plasmids for Ras and $\mathrm{NF} \kappa \mathrm{B}$ activities were Pyz-luc (Galang et al, 1994, 
(a) Western blot analysis on Ras protein

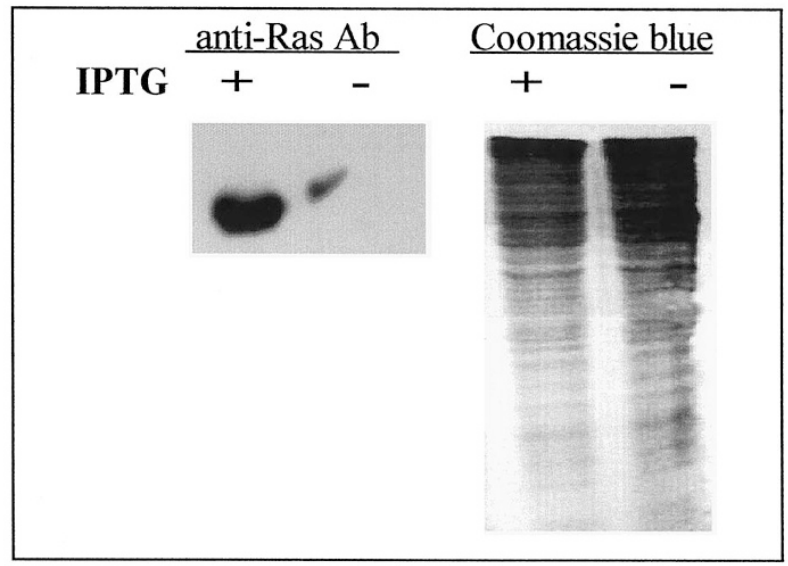

(b) FACScan analysis on Fas-L in 212 cells upon IPTG induction

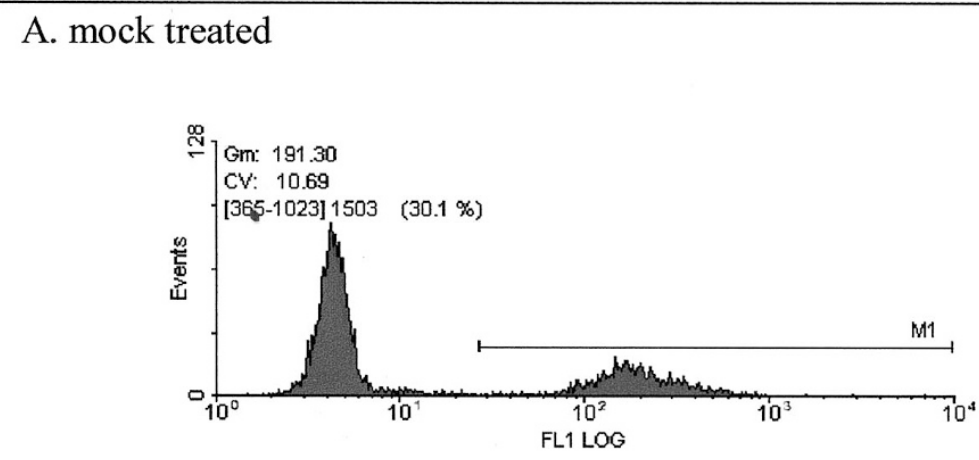

B. IPTG (2.5mM)-induction for $24 \mathrm{~h}$

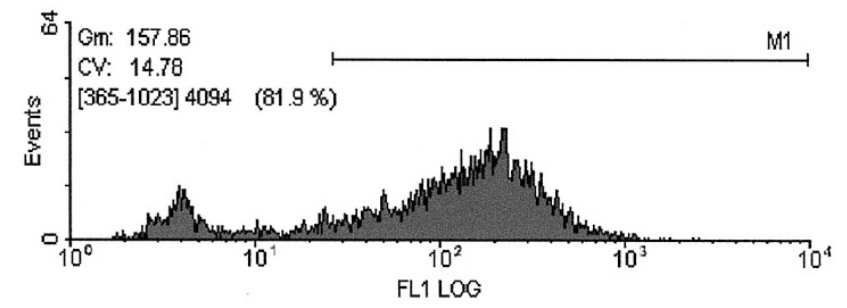

\section{Figure 6.}

Induction of Fas-L expression in murine 212 cells. The 212 cells were stimulated with $2.5 \mathrm{~mm} \mathrm{IPTG} \mathrm{for} 24$ hours. Protein extract was subjected to Western blot analysis on Ras protein using Ras-recognizing antibody and detected with ECL system. a, Identical gel was stained with Coomassie blue and served as protein loading control. b, Fas-L protein was measured by flow cytometric analysis using Fas-L-specific antibody.

kindly provided by Dr. Hauser, The Burnham Institute, La Jolla, California and pNF $\kappa$ B-Luc (Stratagene, La Jolla, California), respectively. The activities of luciferase and $\beta$-galactosidase were determined by the Dual-light luciferase and $\beta$-galactosidase reporter gene assay system (Tropix, Bedford, Massachusetts).

\section{Reversed Transcription-Polymerase Chain Reaction}

Total RNA was prepared by the RNeasy Kit followed the manufacturer's instruction (Qiagen) and converted to cDNA by StrataScrip-H-Reverse transcriptase in the presence of RNAsin (Stratagene) with oligo-dT as 
a primer. RT-PCR on the Fas-L transcripts was performed under conditions described previously (Yang and Yang, 1998). The generated cDNA was subjected to PCR amplification on a DNA thermal Cycler (Hybaid Omnigene, Middlesex, UK). $\beta$-actin served as a semiquantitative control. PCR products were fractionated by agarose electrophoresis, stained with ethidium bromide, and visualized under UV light.

\section{Flow Cytometric Analysis and Immunohistochemical Staining}

Cells were harvested with a cell scraper and suspended in phosphate balanced buffer containing $1 \%$ BSA. They were fixed with ice-cold $4 \%$ formaldehyde for 15 minutes and then permeablized with $0.1 \%$ Tween 20. Fas-L protein was stained with a rabbit anti-Fas-L antibody (N-20; Santa Cruz, California), followed by PE-conjugated rat anti-rabbit Ig antibody (Gibco). Subsequently, cells were subjected to flow cytometry analysis with a gate set for examining a total of $10^{4}$ cells. Fas-L of Ha-ras ${ }^{\text {Val12 }}$-transfected normal glial cells was detected by immunohistochemical staining. Glial cells were transfected with Ha-ras Val12 and pEGFP-N1 at a ratio of 9:1, then grown and treated on poly-L-lysine-coated slides. They were stained in situ with the rabbit anti-Fas- $L$ antibody followed by the PE-conjugated rat anti-rabbit Ig. FasL-positive cells were visible under a fluorescent microscope.

\section{Western Blot Analysis}

On exposure to IPTG for 24 hours, 212 cells were extracted with buffer containing 1\% triton X-100, 10 $\mathrm{mm}$ Tris- $\mathrm{HCl}, \mathrm{pH} 7.4,0.15 \mathrm{M} \mathrm{NaCl}, 0.1 \mathrm{U} / \mathrm{ml}$ aprotinin, and $50 \mu \mathrm{g} / \mathrm{ml}$ PMSF. Proteins were separated in a $12.5 \%$ SDS-polyacrylamide gel and electroblotted onto a nitrocellulose membrane. Ras protein was probed at first with a Ras-specific monoclonal mouse antibody (Ab-2; Oncogene, Cambridge, Massachusetts) followed by peroxidase-conjugated goat anti-mouse lgG antibody (DAKO, Carpinteria, California). The immune complexes were made visible by fluorography with an enhanced chemiluminescence detection kit (Amersham International PLC, Buckingham, UK).

\section{Acknowledgements}

This work was supported in part by grants from the National Science Council, Republic of China, to BCY. We are grateful to Dr. M.D. Lai for critical reading of the manuscript.

\section{References}

Alderson MR, Tough TW, Davis-Smith T, Braddy S, Falk B, Schooley KA, Goodwin RG, Smith CA, Ramsdell F, and Lynch DH (1995). Fas ligand mediates activation-induced cell death in human T lymphocytes. J Exp Med 181:71-77.

Campbell SL, Khosravi-Far R, Rossman KL, Clark GJ, and Der CJ (1998). Increasing complexity of Ras signaling. Oncogene 17:1395-1413.
Capon DJ, Chen EY, Levinson AD, Seeburg PH, and Goeddel DV (1983). Complete nucleotide sequences of the T24 human bladder carcinoma oncogene and its normal homologue. Nature 302:33-37.

Chen X, Zachar V, Zdravkovic M, Guo M, Ebbesen P, and Liu $X$ (1997). Role of the Fas/Fas ligand pathway in apoptotic cell death induced by the human T cell lymphotropic virus type I Tax transactivator. J Gen Virol 78:3277-3285.

Chervonsky AV, Wang Y, Wong FS, Visintin I, Flavell RA, Janeway CA, and Matis L A (1997). The role of Fas in autoimmune diabetes. Cell 89:17-24.

Cuthbert JA and Lipsky PE (1997). Regulation of proliferation and Ras localization in transformed cells by products of mevalonate metabolism. Cancer Res 57:3498-3505.

Faris M, Latinis KM, Kempiak SJ, Koretzky GA, and Nel A (1998). Stress-induced Fas ligand expression in T cells is mediated through a MEK kinase 1-regulated response element in the Fas ligand promoter. Mol Cell Biol 18:5414-24.

Feig LA and Cooper GM (1988). Inhibition of NIH 3T3 cell proliferation by a mutant ras protein with preferential affinity for GDP. Mol Cell Biol 8:3235-3243.

Fenton RG, Hixon JA, Wright PW, Brooks AD, and Sayers TJ (1998). Inhibition of Fas (CD95) expression and Fas-mediated apoptosis by oncogenic Ras. Cancer Res 58:3391-3400.

Ferguson TA and Griffith TS (1997). A vision of cell death: Insights into immune privilege. Immunol Rev 156:167-184.

Fernandez A, Chen PW, Aggarwal BB, and Ananthaswamy $\mathrm{HN}$ (1992). Resistance of Ha-ras oncogene-induced progressor tumor variants to tumor necrosis factor and interferongamma. Lymph Cyt Res 11:79-85.

Galang CK, Der CJ, and Hauser CA (1994). Oncogenic Ras can induce transcriptional activation through a variety of promoter elements, including tanden c-Ets-2 binding sites. Oncogene 9:2913-2921.

Girgert R, Marini P, Janessa A, Bruchelt G, Treuner J, and Schweizer $P$ (1994). Inhibition of the membrane localization of p21 ras proteins by lovastatin in tumor cells possessing a mutated N-ras gene. Oncology 51:320-322.

Gratas C, Tohma Y, Van Meir EG, Klein M, Tenan M, Ishii N, Tachibana O, Kleihues P, and Ohgaki H (1997). Fas ligand expression in glioblastoma cell lines and primary astrocytic brain tumors. Brain Pathol 7:863-869.

Guha A, Feldkamp MM, Lau N, Boss G, and Pawson A (1997). Proliferation of human malignant astrocytomas is dependent on Ras activation. Oncogene 15:2755-2765.

Hahne M, Rimoldi D, Schroter M., Romero P, Schreier M, French LE, Schneider P, Bornand T, Fontana A., Lienard D, Cerottini J, and Tschopp J (1996). Melanoma cell expression of Fas (Apo-1/CD95) ligand: Implications for tumor immune escape. Science 274:1363-1366.

Itoh $\mathrm{N}$, Yonehara $\mathrm{S}$, Ishii $\mathrm{A}$., Yonehara $\mathrm{M}$, Mizushima $\mathrm{S}$, Sameshima M, Hase A, Seto Y, and Nagata S (1991). The polypeptide encoded by the cDNA for human cell surface antigen Fas can mediate apoptosis. Cell 66:233-243.

Kaba DS, Pierceall WE, Price JE, and Ananthaswamy HN (1990). Immune response to progressor variants derived from transfection of an ultraviolet radiation-induced $\mathrm{C} 3 \mathrm{H}$ mouse regressor tumor cell line with activated Harvey-ras oncogene. Cancer Res 50:3159-3166. 
Kasibhatla S, Brunner T, Genestier L, Echeverri F, Mahboubi A, and Green DR (1998). DNA damaging agents induce expression of Fas ligand and subsequent apoptosis in $T$ lymphocytes via the activation of NF-kappa B and AP-1. Mol Cell 1:543-551.

Latinis KM, Carr LL, Peterson EJ, Norian LA, Eliason SL, and Koretzky GA (1997). Regulation of CD95 (Fas) ligand expression by TCR-mediated signaling events. J Immunol 158: 4602-4611.

Liu HS, Chen CY, Lee CH, and Chou YI (1998). Selective induction of oncogenic Ha-ras induced apoptosis in $\mathrm{NIH} / 373$ cell lines. Br J Cancer 77:1777-1786.

Liu HS, Scrable H, Villaret DB, Lieberman MA, and Stambrook PJ (1992). Control of Ha-ras-mediated mammalian cell transformation by Escherichia coli regulatory elements. Cancer Res 52:983-989.

Ljungdahl S, Shoshan MC, and Linder S (1997). Inhibition of the growth of $12 \mathrm{~V}$-ras-transformed rat fibroblasts by acetylsalicylic acid correlates with inhibition of NF-kappa B. AntiCancer Drugs 8:62-66.

Lowy DR and Willumsen BM (1993). Function and regulation of ras Ann Rev Biochem 62:851-891.

Muschel RJ, Willias JE, Lowy DR, and Liotta LA (1985). Harvey ras induction of metastatic potential depends upon oncogene activation and the type of recipient cell. Am J Pathol 1:1-8.

O'Connell J, Bennett MW, O'Sullivan GC, Collins K, and Shanahan F (1999). The Fas-L counterattack: Cancer as a site of immune privilege. Immunol Today 20:46-52.

Saas P, Walker PR, Hahne M, Quiquerez AL, Schnuriger V, Perrin G, French L, Van Meir EG, de Tribolet N, Tschopp J, and Dietrich PY (1997). Fas ligand expression by astrocytoma in vivo: maintaining immune privilege in the brain? J Clin Invest 99:1173-1178.

Seino KI, Kayagaki N, Tsukada N, Fukao K, Yagita H, and Okumura K (1997). Transplantation of CD95 ligandexpressing grafts: Influence of transplantation site and difficulty in protecting allo- and xenografts. Transplantation 64: 1050-1054.

Solana R, Romero J, Alonso C, and Pena J (1992). MHC class I antigen expression is inversely related with tumor malignancy and ras oncogene product (p21ras) levels in human breast tumors. Invas Metastasis 12:210-217.

Strand S, Hofmann WJ, Hug H, Muller M, Otto G, Strand D, Mariani SM, Stremmel W, Krammer PH, and Galle PR (1996). Lymphocyte apoptosis induced by CD95 (APO-1/Fas) ligand-expressing tumor cells: $A$ mechanism of immune evasion? Nature Med 2:1361-1366.
Takahashi T, Tanaka M, Inazawa J, Abe T, Suda T, and Nagata S (1994). Human Fas ligand: Gene structure, chromosomal location and species specificity. Int Immunol 6:1567-1574.

Tsuda T, Marinetti MR, Masuelli L, and Cutler ML (1995). The Ras suppressor RSU-1 localizes to 10p13 and its expression in the U251 glioblastoma cell line correlates with a decrease in growth rate and tumorigenic potential. Oncogene 11:397403.

Tsurushima H, Tsuboi K, Yoshii Y, Ohno T, Meguro K, and Nose T (1996). Expression of $\mathrm{N}$-ras gene in gliomas. Neurologia Medico-Chirurgica 36:704-708.

Van Parijs L and Abbas AK (1996). Homeostasis and selftolerance in the immune system: Turning lymphocytes off. Science 280:243-248.

Walker PR, Saas P, and Dietrich PY (1998). Tumor expression of Fas ligand (CD95L) and the consequences. Curr Opin Immunol 10:564-572.

Wang B, Soule HD, and Miller FR (1997). Transforming and oncogenic potential of activated c-Ha-ras in three immortalized human breast epithelial cell lines. Anticancer Res 17: 4387-4394.

Weijzen S, Velders MP, and Kast WM (1999). Modulation of the immune response and tumor growth by activated Ras. Leukemia 13:502-513.

White MA, Nicolette C, Minden A, Polverino A, Van Aelst L, Karin M, and Wigler MH (1995). Multiple Ras functions can contribute to mammalian cell transformation. Cell 80:533541.

Yang BC and Yang TL (1998). Differential expression of cytokine genes and apoptosis in glioma cell lines upon exposure to bacteria and lipopolysaccharides. J Microbiol Immunol Infect 31:95-100.

Yeh WC, Pompa JL, McCurrach ME, Shu HB, Elia AJ, Shahinian A, Ng M, Wakeham A, Khoo W, Mitchell K, El-Deiry WS, Lowe SW, Goeddel DV, and Mak TW (1998). FADD: Essential for embryo development and signaling from some, but not all, inducers of apoptosis. Science 279:1954-1958.

Yong VM, Yong FP, Ruijs TCG, Antel JP, and Lim SU (1991). Expression and modulation of HLA-DR on culture human adult astrocytes. J Neuropathol Exp Neurol 50:16-28. 